\title{
POLITIKK
}

\section{Stater og transnasjonale motstandsnettverk: Irans mobilisering av irakiske sjiamilitser etter I979}

\author{
Henriette U. Erstad ${ }^{\star}$ \\ Norsk Utenrikspolitisk Institutt (NUPI)
}

\begin{abstract}
Sammendrag
Den islamske republikken Iran har bygd et transnasjonalt nettverk av sjiamilitser siden 1979, ofte referert til som dens asymmetriske krigføringsstyrke og 'strategiske dybde'. Mens det er velkjent at Iran har mobilisert disse aktørene for å styrke sin regionale posisjon, har hvordan den har gjort det blitt viet lite vitenskapelig oppmerksomhet. Denne artikkelen forsøker derfor å forklare dette fenomenet ved å undersøke hvordan Iran har mobilisert irakiske sjiamilitser siden 1979. De utvalgte analyseenhetene representerer de mest innflytelsesrike sjiamilitsene med tilknytning til Iran i Irak i dag: Badr Organisation, Asa'ib Ahl al-Haq og Kata'ib Hizbullah. Selv om variasjon eksisterer mellom dem, er alle del av et transnasjonalt nettverk som har hjulpet Iran med å delta i skjult og/eller indirekte konfliktintervension i Midtøsten i flere tiår. Den komparative casestudien har blitt benyttet som forskningsdesign, med prosessporing og semi-strukturerte intervjuer som metode for datainnsamling. Den empiriske analysen har blitt rettledet av et teoretisk rammeverk som har forsøkt å bygge en bro mellom contentious politics og eksisterende litteratur om dynamikken mellom stater og væpnede opprørere. De empiriske funnene antyder at Iran har opptrådt som en sekterisk entreprenør som på pragmatisk vis har kombinert sine materielle og ikke-materielle ressurser for å mobilisere likesinnede militser til å delta i kollektiv vold og fremme felles krav.
\end{abstract}

Nøkkelord: mobilisering $\cdot$ væpnede grupper $\cdot$ Midtøsten $\cdot$ Iran $\cdot$ Irak

\footnotetext{
^Kontaktinformasjon: Henriette U. Erstad, e-post: henrietteue@nupi.no

(C)2019 Henriette U. Erstad. This is an Open Access article distributed under the terms of the Creative Commons Attribution 4.0 International License (http://creativecommons.org/licenses/by/4.0/), allowing third parties to copy and redistribute the material in any medium or format and to remix, transform, and build upon the material for any purpose, even commercially, provided the original work is properly cited and states its license.

Citation: Henriette U. Erstad (2019). Stater og transnasjonale motstandsnettverk: Irans mobilisering av irakiske sjiamilitser etter 1979. Internasjonal Politikk, 77(3): 296-322. http://dx.doi.org/10.23865/intpol.v77.1597
} 


\section{Innledning}

Den islamske republikken Irans innflytelse i Levanten, særlig Irak og Syria, er sterkere enn noen gang. For å oppnå dette har Iran benyttet seg av en ganske så ukonvensjonell ressurs - sjiamilitser. Selv om denne utviklingen ofte settes i sammenheng med den amerikanskledede invasjonen av Irak i 2003 (Arango, 2017; Majidyar, 2017b; South, 2019), kan den spores tilbake til revolusjonen i 1979 og målet om å eksportere den. Siden Iran ikke kan måle seg med rivaler som USA og Israel når det kommer til tradisjonelle maktmidler, har de bygd opp en asymmetrisk krigføringsstyrke bestående av titalls væpnede grupper som nå strekker seg fra Teheran til Beirut via Bagdad og Damaskus (se f.eks. Ostovar, 2016). Ifølge Irans øverste leder, ayatollah Ali Khamenei, er dette Irans «strategiske dybde» i Midtøsten (se Sadeghi-Boroujerdi, 2017). Irans transnasjonale nettverk av sjiamilitser har derfor vekket like stor bekymring blant arabiske og vestlige beslutningstakere som landets konvensjonelle militære styrker, atomvåpenprogram eller ballistiske missiler. Hvordan Iran har klart å mobilisere disse gruppene, har imidlertid ikke blitt viet mye vitenskapelig oppmerksomhet.

Denne artikkelen vil forsøke å forklare hvordan Iran har mobilisert irakiske sjiamilitser siden 1979, ved å undersøke mobiliseringsprosessene til Badr Organization,

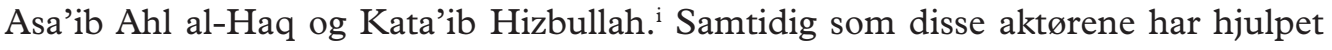
Iran med å delta i både skjult og indirekte konfliktintervensjon i flere tiår, har de langt større handlingsevne enn såkalte stedfortredere. Med støtte og veiledning fra Iran har de nemlig utviklet seg fra å være væpnede motstandsgrupper til å få stadig større fotfeste i det irakiske samfunn. Militsenes massemobilisering under paraplyorganisasjonen Hashd al-Sha'abi (Folkets mobiliseringsstyrke) etter Den islamske statens (IS) fremvekst i 2014 bidro ytterligere til denne prosessen. De er nå en formalisert del av Iraks regulære sikkerhetsstyrker, kontrollerer territorier de har gjenvunnet fra IS, tilbyr velferdstjenester og beskyttelse i sårbare samfunn, leder gjenoppbyggingsprosesser, er integrert i landets (u)formelle økonomi og er tungt representert i både regjeringen og parlamentet. ${ }^{\text {ii }}$

Irans militsstrategi har dermed vært omfattende og langsiktig. Teheran har nå mulighet til å påvirke utviklingen i Irak både nedenfra og opp og ovenfra og ned i overskuelig fremtid, på samme måte som med Hizbullah i Libanon (se f.eks. Alaaldin, 2018; Eisenstadt \& Knights, 2017).iii Den "sorte boksen» av iransk statskunst som har bidratt til dette, er derfor et interessant fenomen i seg selv. ${ }^{\text {iv }}$ I tillegg er det et interessant tilfelle av hvordan stater bidrar til mobiliseringsprosesser utenfor egne landegrenser, samt hvordan dette kan være en form for skjult og/eller indirekte konfliktintervensjon. Selv om det finnes mye faglitteratur som undersøker dynamikken mellom stater og væpnede opprørere, har fokuset også ofte vært på hvorfor - ikke hvordan - denne typen forhold oppstår. ${ }^{v}$ Mange av disse studiene har i tillegg vektlagt betydningen av tradisjonelle former for statlig støtte, som for eksempel økonomiske eller militære midler. ${ }^{\text {vi }}$ Denne artikkelen ønsker å bidra til å fylle dette kunnskapshullet. 


\section{Teoretisk rammeverk}

Det teoretiske rammeverket som har bidratt til å strukturere den empiriske analysen, har forsøkt å bygge en bro mellom omstridt politikk ("contentious politics») og eksisterende litteratur om dynamikken mellom stater og væpnede opprørere. Innen førstnevnte litterære landskap har det blitt tillagt et særlig fokus på sekterisk entreprenørskap, som har en instrumentell tilnærming til mobilisering. For å strukturere analysen og gjennomgå empirien på en hensiktsmessig måte har det blitt tatt utgangspunkt i mekanismer, også med det formål å undersøke i hvilken grad Irans mobilisering av militser kan sies å ha utgjort en robust prosess.

\section{Sekterisk entreprenørskap}

Eskandar Sadeghi-Boroujerdi (2017, s. 169) har foreslått at de irakiske sjiamilitsene bør forstås som «væpnet og politisert sosial handling» og dermed en form for omstridt politikk. Irans mobilisering av irakiske sjiamilitser vil her analyseres som nettopp dette. Én viktig årsak til det er at væpnede ikke-statlige eller delvis statlige grupper ofte oppstår fra sosiale bevegelser, her forstått som «mobiliseringen av et stort antall mennesker for å utfordre makt og presse på for (eller motstå) sosial endring» (Romano, 2017, s. 17). Utgangspunktet for denne artikkelen er at en ekstern stat har vært involvert $\mathrm{i}$ en slik mobiliseringsprosess, og med artikkelens historiske forankring er det analyseenhetens opphav i den sjiaislamistiske bevegelsen i Irak som vil utgiøre en sentral del av den empiriske analysen. Omstridt politikk er med andre ord et fruktbart teoretisk utgangspunkt for en artikkel som forsøker å forklare hvordan Iran har mobilisert irakiske sjiamilitser siden 1979.

Aktører som har hatt en vesentlig rolle i å mobilisere ressursene som trengs for å utføre kollektiv handling, blir ofte referert til som politiske entreprenører (Della Porta \& Diani, 2006, s. 14). Materielle ressurser som våpen og penger er imidlertid ikke nødvendigvis tilstrekkelig for politiske entreprenører som mobiliserer individer og/eller grupper til å delta i kollektiv vold. Della Porta og Diani (2006, s. 94) har for eksempel argumentert for at kollektiv handling ikke vil finne sted uten tilstedeværelsen av et «vi» som identifiserer felles egenskaper og en spesifikk solidaritet. Paul Staniland (2015, s. 152) har også hevdet at væpnede grupper og nettverk er mest effektive i å mobilisere kollektiv handling dersom de har en overlappende sosial base, i og med at de da vil ha større sannsynlighet for å lykkes med å samarbeide på tvers av «lokaliteter». Ofte innebærer dette å ha en enhetlig, sentral autoritet samtidig som det trenes til kamp lokalt, noe som gjerne forutsetter et bånd som styrker både tillit og felles formål (Staniland, 2015, s. 152). I tråd med dette kan dermed «kostnaden» for å oppnå en gruppes lojalitet være korrelert med graden av for eksempel sekterisk eller ideologisk overlapp mellom patron og klient (Bapat, 2012, s. 5; Sadeghi-Boroujerdi, 2017, s. 175). Ifølge Elisabeth J. Wood (2013, s. 257) er også «transnasjonal mobilisering av allierte mer sannsynlig når det gjelder konflikter langs religiøse (eller etniske) skillelinjer, enn der disse er fraværende». 
I denne sammenheng er Nader Hashemis og Danny Postels (2017) begrep sekterisering ("sectarianization»), definert som "en prosess formet av politiske aktører som opererer innenfor spesifikke kontekster og forfølger politiske mål som involverer populær mobilisering rundt spesielle (religiøse) identitetsmarkører», illuminerende. Madawi Al-Rasheed (2017, s. 158) har på sin side beskrevet dette som "et moderne politisk fenomen som næres av hardnakkede diktatorers avhengighet av å kalle på disse gamle religiøse og dødelig politiserte identitetene for å holde på sitt styre». I tråd med dette har Toby Matthiesen (2014) argumentert for at disse elitene derfor kan forstås som entreprenører i sekterisk identitet. Selv om det må tas høyde for at sekteriske entreprenører ikke er de eneste som «aktiverer» sekterisk identitet, spiller de uten tvil en medvirkende rolle (se Wehrey, 2014, s. xiv). Denne typen prosesser formes også av en rekke faktorer, som klassedynamikk, statlig sårbarhet, kriger og revolusjoner, geopolitisk rivalisering og ekstern innblanding (Hashemi \& Postel, 2017, s. 4; Wehrey, 2014, s. xiv).

For å få en bedre forståelse av hvordan sekterisk entreprenørskap fungerer i praksis, antyder Hashemi og Postel $(2017$, s. 5) at etnisk mobilisering er relevant. De to mest innflytelsesrike tilnærmingene til etnisk mobilisering har vært primordialisme og instrumentalisme (Nasr, 2017, s. 81; Varshney, 2007, s. 282). Primordialisme ser på etnisitet som «en subjektiv følelse av delt identitet», eller med andre ord «et naturlig fenomen som er dypt innebygd i menneskets psykologi og sosiale relasjoner» (Nasr, 2017, s. 81). Instrumentalister, derimot, ser på etnisitet som «verken iboende i menneskets natur eller verdifullt i seg selv» (Varshney, 2007, s. 282). Etniske eller religiøse identiteter brukes heller til å tilegne seg politisk makt eller hente ressurser fra staten og maskerer derfor en dypere kjerne av politiske eller økonomiske interesser (Nasr, 2017, s. 81; Varshney, 2007, s. 282). Videre argumenterer instrumentalister for at gruppekonflikt er et resultat av konkurranse om makt mellom politiske eliter (eller sekteriske entreprenører) som utnytter eller manipulerer identiteter for å fremme sine egne interesser (Nasr 2017, s. 81). Etnisk eller religiøst motivert vold er dermed ofte drevet frem av disse elitene (se også Lynch, 2013).

Dersom Iran har opptrådt som en sekterisk entreprenør i mobiliseringen av sjiamilitser, bør landet altså anses som involvert i utforming og implementering av mobiliseringsmekanismer med det formål å oppnå egne politiske mål. Når man skal se nærmere på en så omfattende prosess som mobilisering, mener Tilly og Tarrow (2015, s. 28) at man bør 1) beskrive prosessen, 2) stykke den opp i ulike bestanddeler (her mekanismer) og 3) bruke dette som utgangspunkt for å utforme en mer generell redegjørelse som forsøker å forklare hvordan prosessen har funnet sted.Ved å følge disse trinnene kan vi også undersøke om visse mekanismer sammenfaller så regelmessig og med så lignende utfall at de utgiør en robust prosess (Tilly \& Tarrow, 2015, s. 30). Man observerer gjerne de samme mekanismene i lokale så vel som i transnasjonale mobiliseringsprosesser (Adamson, 2013, s. 67), noe som giør mekanismene som skisseres av Tilly og Tarrow, velegnet også for en artikkel som forsøker å forklare hvordan en stat bidrar til mobiliseringsprosesser utenfor egne landegrenser. 


\section{Mekanismer for mobilisering}

Tilly og Tarrow (2015, s. 74) definerer mobilisering som «en økning av ressurser tilgjengelig for en politisk aktør til å fremme kollektive krav». Med andre ord innebærer dette at en gruppe mennesker som på et gitt tidspunkt ikke fremmer slike krav, begynner å giøre det. I et forsøk på å stykke opp mobiliseringsprosessene i sine bestanddeler på en meningsfylt måte har mekanismer blitt valgt ut basert på både teoretiske forventninger og empiriske observasjoner. Kort fortalt vil en mekanisme her forstås som en redegjørelse $(\mathrm{Z})$ for hvordan $\mathrm{X}$ og Y er forbundet med hverandre.

Basert på den teoretiske diskusjonen over har jeg tatt utgangspunkt i fire mekanismer som har fungert som en rettesnor for den empiriske analysen: megling, indoktrinering, koordinert handling og sosial tilegnelse. Mekanismene har hovedsakelig blitt hentet fra Tilly og Tarrow (2015), med unntak av indoktrinering, som har blitt utledet fra litteraturen om sekterisk entreprenørskap. Tidligere studier av libanesiske Hizbullah har også vært veiledende i valg av mekanismer, i og med at denne gruppen ofte blir ansett som en slags modell for hvordan Iran samarbeider med ikke-statlige eller delvis statlige væpnede grupper (se Alaaldin, 2018; Eisenstadt \& Knights, 2017; Smyth, 2015). Utvalg av mekanismer har derfor vært både induktivt og deduktivt, mye fordi eksisterende litteratur ikke foreslår en tydelig årsakskjede for den kausale prosessen som oppstår i et komplekst sosialt fenomen som militsmobilisering.

\section{Megling}

Med utgangspunkt i Tillys og Tarrows definisjon (2015, s. 31) vil megling her forstås som å skape en forbindelse mellom enheter som tidligere har vært frakoblet. Ifølge eksisterende forskning på sosiale nettverk er meglere innflytelsesrike aktører som får enda større makt gjennom deres evne til å gjøre nettopp dette (Adamson, 2013, s. 68-69). I og med at analyseenhetene i denne artikkelen anses som del av et transnasjonalt nettverk, vil meglervirksomhet her bli sett på som både det å skape en forbindelse mellom megleren selv og grupper/individer samt å koble de sistnevnte med hverandre. I tillegg vil det å skape en forbindelse mellom enheter og en konflikt bli ansett som en form for meglervirksomhet (se f.eks. Adamson 2017, s. 69). Ressurser som benyttes til dette er ofte materielle, som for eksempel militære og økonomiske midler, men de kan også være ikke-materielle, som for eksempel når en aktør styrker sin evne til å delta, i kollektiv handling ved å bruke religiøse eller ideologiske identitetsmarkører. Som sådan kan indikatorer på megling inkludere å bidra med både materielle ressurser (f.eks trening, utstyr, penger) og ikke-materielle ressurser (f.eks religiøs eller ideologisk veiledning) for å skape en forbindelse mellom enheter og konflikten.

\section{Indoktrinering}

Tidligere forskning (Bakke, 2013) har vist at samhandling med en ekstern aktør ofte kan føre til at en sosial bevegelse endrer mål. Med utgangspunkt i litteraturen om 
sekterisk entreprenørskap kan religiøs eller ideologisk påvirkning ha vært en bidragsytende faktor til dette. En mekanisme som benyttes i mobiliseringsprosesser, kan derfor være indoktrinering, som kort forklart går ut på at en aktør aktivt og bevisst forsøker å overbevise en annen aktør om å tilegne seg sitt verdensbilde. I denne sammenheng er det Tilly og Tarrow (2015, s. 37) refererer til som identitetsskifte, altså det som skjer «når nye identiteter dannes som resultat av at grupper bringes sammen $\mathrm{i}$ kollektiv handling og oppdager likhetstrekk» (Tilly \& Tarrow 2015, s. 37), illustrerende. For å fange den eksterne aktørens rolle i denne prosessen vil identitetsskifte her behandles som en indikator på at indoktrinering har funnet sted, heller enn en mekanisme i seg selv. Identitet kan defineres som «en sosial kategori som ikke bare uttrykker betydningen en aktør tilskriver selvet, men snarere selvdefinisjoner relatert til definisjoner 'jeget' tilskriver andre og andre tilskriver 'jeget'» (Campbell, 1998, s. 12-13). Det er viktig å påpeke at indoktrinering her vil forstås som en kontinuerlig prosess, heller enn en slags mekanisme som opphører å eksistere etter at den har blitt anvendt.

Indikatorer på at denne mekanismen har vært vellykket i å mobilisere grupper og/eller individer, vil naturligvis avhenge av kontekst, men innenfor denne artikkelens teoretiske rammeverk er det særlig interessant å se på religiøse og ideologiske manifestasjoner. Dette kan for eksempel være at aktørene deltar i strategisk fremstilling av felles språklige virkemidler, her forstått som at «en gruppe mennesker strategisk og bevisst fremstiller delte forståelser av verden og seg selv som legitimerer og motiverer kollektiv handling» (McAdam, McCarthy, Zald \& Mayer, 1996, s. 6). Ifølge Della Porta og Diani (2006, s. 93) blir identitet ofte konstruert gjennom hvordan man definerer grensene mellom de ulike aktørene i en konflikt, og et eksempel på strategisk fremstilling kan derfor være å male fiendebilder ved å fyre opp under forskjeller mellom «oss» og «dem», både i ideologiske og sekteriske termer.

\section{Koordinert handling}

Selve grunnmuren i en sosial bevegelses mobiliseringsprosess er deltagelse i koordinert handling, som "oppstår når to eller flere aktører deltar i gjensidig signalisering og gjør krav på samme objekt parallelt» (Tilly \& Tarrow, 2015, s. 31). I tråd med den instrumentelle tilnærmingen til mobilisering tas det her utgangspunkt $\mathrm{i}$ at aktøren som mobiliserer, gjør dette fordi det anses som å tjene egne interesser. Tidligere forskning på dynamikken mellom stater og væpnede opprørere støtter også dette, selv om det må understrekes at sistnevnte i mange tilfeller har for stor handlingsevne («agency») til å kunne forstås som klienter eller såkalte stedfortredere. Det at Iran og sjiamilitsene har deltatt i koordinert handling, er ikke nødvendigvis interessant i seg selv - dette er veldokumentert. Det som imidlertid er interessant å se nærmere på, er i hvilken grad koordinert handling mellom den eksterne aktøren og grupper og/eller individer har vært en effektiv mobiliseringsmekanisme for førstnevnte tidlig i prosessen. Like viktig er det å undersøke 


\section{Henriette U. Erstad}

mekanismens samspill med de andre mekanismene under mobiliseringsprosessens hendelsesforløp, noe som kan gi empirisk innsikt i hvordan den mobiliserende aktøren går frem.

Sosial tilegnelse

Sosial tilegnelse skjer når «ikke-politiske grupper forvandles til politiske aktører ved å bruke sine organisatoriske og institusjonelle baser til å iverksette bevegelseskampanjer» (Tilly \& Tarrow, 2015). I denne artikkelens kontekst vil sosial tilegnelse også forstås som et strategisk grep som tas for å øke bevegelsens oppslutning eller lojalitet blant befolkningen i områdene den opererer i. Dette kan for eksempel skje gjennom å tilby offentlige goder ved å etablere en sosial velferdsarm (se f.eks. Grynkewich, 2008). I tillegg til å gi fordeler i bevegelsens etableringsfase kan det også være en måte å sikre sitt raison d'être selv om omgivelsene går over i en tilstand av fred og stabilitet. Da Hizbullah utviklet seg fra å være en væpnet motstandsgruppe til å et politisk parti med reell innflytelse i formelle beslutningsprosesser i Libanon, var dette en mekanisme som ble benyttet. ${ }^{\text {vii }}$ I og med at Hizbullah ofte anses som Irans mest vellykkede "oppnåelse» i det transnasjonale nettverket av motstandsgrupper, er det interessant å se i hvilken grad denne mekanismen også har blitt brukt i mobiliseringsprosessene av irakiske sjiamilitser.

Tabell 1 Mekanismer og indikatorer

\begin{tabular}{ll}
\hline Mekanisme & Indikator på at mekanisme har blitt brukt \\
\hline Megling & $\begin{array}{l}\text { Produksjon av en forbindelse mellom enheter som tidligere har vært frakoblet } \\
\text { (hovedsakelig mellom Iran og en milits, men også mellom militser) }\end{array}$ \\
Indoktrinering & $\begin{array}{l}\text { Endring av identitet (gruppeidentitet endres før eller etter at forhold til ekstern aktør er } \\
\text { etablert); avsløring av religiøse eller ideologiske fellestrekk som tidligere har vært ukjent }\end{array}$ \\
$\begin{array}{l}\text { Koordinert } \\
\text { handling }\end{array}$ & $\begin{array}{l}\text { Kollektiv vold; felles fremstilling av krav; strategisk bruk av felles, språklige } \\
\text { virkemidler }\end{array}$ \\
& $\begin{array}{l}\text { Transformasjon til politisk parti (lansering av politisk kampanje etc.); etablering av } \\
\text { sosiale velferdstjenester }\end{array}$ \\
\hline
\end{tabular}

\section{Kort om metode og analyseenheter}

Den komparative casestudien har blitt benyttet som forskningsdesign, med prosessporing og semistrukturerte intervjuer som metoder for datainnsamling. Av hensyn til at casene er både uoversiktlige og detaljrike, har prosessporing fungert godt for å kunne kartlegge i hvilken rekkefølge de ulike mobiliseringsmekanismene har blitt brukt. Dette har krevd en relativt omfattende gjennomgang av tilgjengelig tekstmateriale, som tidligere forskning, nyhetsartikler, statlige dokumenter og annen relevant litteratur. De semistrukturerte intervjuene har på sin side vært avgjørende for å se empirien i tråd med lokale oppfatninger samt for å sikre datatriangulering. Intervjuene ble gjennomført i Erbil, Suleimania og Chamchamal i mars 2018, og intervjuobjektene var politikere, forskere og journalister med dyptgående kunnskap 
om tema. ${ }^{1}$ Begge datainnsamlingsmetoder krever følgelig en kritisk vurdering av informasjonens autentisitet, relevans, troverdighet og nøytralitet, noe undertegnede har forsøkt å oppnå etter beste evne.

For å undersøke hvordan Iran har mobilisert irakiske sjiamilitser siden 1979, har følgende analyseenheter blitt valgt: Badr Organization, Asa'ib Al al-Haq og Kata'ib Hizbullah. I og med at Badr Organization ble opprettet som militsen til Det øverste råd for islamsk revolusjon i Irak i 1982, med navnet Badr-brigadene, er det mobiliseringen av disse som vil bli redegjort for i denne artikkelen. Casene representerer mobiliseringsprosesser som skjedde under svært forskjellige omstendigheter. Mens Det øverste råd for islamsk revolusjon i Irak var en væpnet opposisjonsgruppe som ønsket å erstatte Baath-regimet med en islamsk republikk à la den iranske modellen, ble Asa'ib Ahl al-Haq og Kata'ib Hizbullah opprettet under den USA-ledede okkupasjonen av Irak med det formål å angripe koalisjonsstyrker. Selv om variasjon eksisterer mellom dem, er alle del av et transnasjonalt nettverk som har hjulpet Iran med å delta i skjult og/eller indirekte konfliktintervensjon i flere tiår.

Utvalget av et begrenset antall caser har blitt gjort med den hensikt å gå i dybden av et komplekst sosialt fenomen. I og med at det finnes lite eksisterende litteratur som forsøker å forklare hendelsesforløpet til denne typen mobilisering, er formålet også å bidra til teorigenerering underveis. For å kunne undersøke i hvilken grad Irans fremgangsmåte kan sies å utgiøre en gjentakende prosess, hadde det naturligvis vært mer hensiktsmessig å inkludere flere caser, både fra andre tidsperioder og andre geografiske områder. En inngående studie av tre grupper har derfor vært utført på bekostning av generalisering, også når det gjelder staters mobilisering av væpnede grupper for øvrig. Imidlertid har utvalget muliggiort en inngående studie av tre irakiske sjiamilitser som er svært interessante i seg selv, ettersom det er veldokumentert at det er disse gruppene som har nærmest tilknytning til Iran, og i tillegg kan de sies å være de mest innflytelsesrike i Irak i dag.

Det øverste råd for islamsk revolusjon i Irak og Badr-brigadene

Det øverste råd for islamsk revolusjon i Irak (Supreme Council for Islamic Revolution in Iraq, SCIRI) stammer fra den sjiaislamistiske bevegelsen i Irak og anses som en avlegger av Hizb al-Da'wa al-Islamiyya, også kjent som Dawa-partiet (Hashim, 2005, s. 257; Marinova, 2017, s. 242). Det ble grunnlagt av den sjiaislamistiske lederen Muhammad Baqir al-Hakim i Teheran i 1982, med god hjelp fra ayatollah Ruhollah Khomeini og hans nyetablerte islamske republikk. SCIRI var opprinnelig en paraplyorganisasjon som forsøkte å samle de forskjellige opposisjonsgruppene, hovedsakelig sjiaislamister, som levde i eksil i Iran. I 1983 opprettet SCIRI

\footnotetext{
${ }^{1}$ Se vedlegg 1 for full oversikt over intervjuobjekter. Alle transkripsjoner er tilgjengelige ved forespørsel.
} 


\section{Henriette U. Erstad}

sin egen milits, Badr-brigadene (Badr), i tett samarbeid med den iranske revolusjonsgarden. Både SCIRI og Badr opererte fra Iran frem til 2003, da Baath-regimets fall muliggjorde opposisjonens retur til Irak. I dag har SCIRI blitt omdøpt til Iraks øverste islamske råd (Islamic Supreme Council of Iraq, ISCI), mens Badr har blitt en uavhengig enhet med navnet Badr-organisasjonen for gjenoppbygging og utvikling (Badr Organization of Reconstruction and Development). Badrorganisasjonen har i dag mellom ti og femten brigader i Hashd al-Sha'abi og ledes av Hadi al-Ameri.

Asa'ib Ahl al-Haq

Asa'ib Ahl al-Haq (AAH) er en irakisk sjiamilits som oppsto som en utbrytergruppe fra Sadrist-bevegelsens milits Jaysh al-Mahdi i 2004 (se Stanford University, 2018; Cochrane, 2009). Jaysh al-Mahdi (JAM) ble opprettet av Muqtada al-Sadr i 2003 som en væpnet motstandsfront, og mottok i likhet med andre militser materiell støtte fra Iran (Nada \& Rowan, 2018; Roggio, 2007, 2008). AAH erklærte seg imidlertid som en uavhengig enhet i januar 2006 (Cochrane, 2009; Sowell, 2015). Seniormedlem og kommandør i Sadrist-bevegelsen, Qais al-Khazali, er AAHs grunnlegger og generalsekretær. Gruppen er også kjent som Khazalinettverket, som ofte ble omtalt som en "spesialgruppe» av USA, fordi den var bedre trent, finansiert og bevæpnet enn andre militser (Knights, 2010). Ifølge estimater har gruppen mer enn 10000 medlemmer (Counter Extremism Project, 2018; Majidyar, 2018a). AAH representerer i dag den 41., 42. og 43. brigaden i Hashd al-Sha'abi (Al-Tamimi, 2017). Gruppen har også operert i Syria i samarbeid med den iranske revolusjonsgarden, Hizbullah og andre sjiamilitser (se f.eks. Al-Salhy, 2013; Knights, 2019).

Kata'ib Hizbullah

Kata'ib Hizbullah $(\mathrm{KH})$ er en irakisk sjiamilits som ble grunnlagt av Abu Mahdi al-Muhandis med hjelp fra den iranske revolusjonsgarden i 2007 (se Stanford University, 2016). I dag er Muhandis kjent som Iraks assisterende nasjonale sikkerhetsrådgiver og nestkommandør for Hashd al-Sha'abi (Haddad, 2018). I likhet med $\mathrm{AAH}$ anses også $\mathrm{KH}$ som en såkalt spesialgruppe, og gruppen er særlig kjent for å ha mottatt mer sofistikert opptrening og sensitivt utstyr enn andre militser (se Juneau, 2015, s. 110; Knights, 2010). Qasem Soleimani, generalmajor i den iranske revolusjonsgardens Quds-styrken, har tidligere uttalt at Muhandis har «nøkkelen til Irans våpenlager» (Toumaj, 2018). Gruppen regnes for å være en av Iraks mest hemmelighetsfulle sjiamilitser, og lite er kjent om antall medlemmer, selv om nylige estimater anslår at det er ca. 10000 (se Knights, 2019). KH representerer i dag den 45. brigaden i Hashd al-Sha'abi (se Al-Tamimi, 2017). I likhet med AAH har KH også operert i Syria i samarbeid med den iranske revolusjonsgarden, Hizbullah og andre sjiamilitser (se f.eks. Al-Salhy, 2013; Knights, 2019). 


\section{Empirisk analyse}

I denne delen vil mobiliseringsprosessene til de tre analyseenhetene og Irans rolle i disse analyseres. Den empiriske fremstillingen er strukturert i tilfeldig rekkefølge etter mekanismer, hvorav funnene vil diskuteres i lys av hverandre underveis. ${ }^{\text {viii }}$

\section{Megling}

Ifølge Tillys og Tarrows (2015) definisjon består megling av å skape en forbindelse mellom enheter som ikke tidligere har vært tilkoblet. For å giøre denne mekanismen målbar var en indikator på megling at Iran hadde produsert eller tilrettelagt for en slik forbindelse mellom seg selv og en milits, eller mellom militser. Selv om dette var intuitivt, dersom man tar utgangspunkt i hvordan megling defineres i litteraturen, antyder de empiriske funnene at virkeligheten er langt mer sammensatt. Frakobling av tidligere tilkoblede enheter ser nemlig ut til å ha vært en like viktig mekanisme for Iran $i$ alle tre tilfeller. Dette var et aspekt ved megling som ikke var teoretisk forventet.

La oss starte med SCIRI, hvor de empiriske funnene peker på at Iran har bidratt til en økende splittelse mellom Hakim-leiren, som utgjorde SCIRIs lederskap, og Dawa-partiet tidlig på 1980-tallet. Selv om Hakim-familien lenge hadde vært innflytelsesrike medlemmer av Dawa-partiet, forlot sistnevnte SCIRI allerede i 1984 i et forsøk på å distansere seg fra Iran (Shanahan, 2004, s. 947). Årsaken til dette ser ut til å ha vært at Dawa-partiet, i motsetning til SCIRIs lederskap, nektet å adoptere Khomeinis sjiadoktrine Velayat-e faqih (Yamao, 2008, s. 238). Det bør her nevnes at tolvskolens sjialærde har et motstridende syn på forholdet mellom religion og politikk. Mens denne doktrinen fremmer den rettslærdes styre, tar Iraks geistlige et mer kvietistisk standpunkt ved å hevde at religiøse autoriteter ikke bør være politisk aktive (se Selvik, 2018; Vogt, 2012). I tillegg til teologiske uenigheter skal Dawa-partiet heller ikke ha ønsket å kjempe mot egne landsmenn på slagmarken under Iran-Irak-krigen (Pierpaoli Jr., 2013, s. 403). Iran opplevde dermed en viss uforutsigbarhet i samarbeidet mellom de to (International Crisis Group, 2007, s. 2-4). I og med at Iran ønsket at SCIRI etter hvert skulle erstatte Baath-regimet med en islamsk republikk à la den iranske modellen, kan Dawa-partiet dermed ha blitt ansett som et hinder for iranske interesser på sikt.

Blant sjiaene [i Irak] har Iran motarbeidet de grupperingene som har vært mindre nærliggende iransk ideologi enn andre. Dette har tillatt, eller i det minste tilrettelagt for, at de som er vennlig innstilt mot eller likesinnet med Iran, har beholdt makten i Irak [...] Når Iran strekker ut hånden til en gruppe, sier de ikke direkte eller eksplisitt at de har visse betingelser. Fra et strategisk synspunkt vil en betingelse likevel være at gruppen ikke motsetter seg Irans regionale interesser. Som en hovedregel kan en jo ikke inngå et partnerskap eller koordinere med noen og samtidig være imot deres agenda. ${ }^{2}$

\footnotetext{
${ }^{2}$ Intervju av Arif Qurbani, redaktør i avisen Xendan, Chamchamal, Irak, mars 2018.
} 


\section{Henriette U. Erstad}

I AAHs tilfelle kommer dette aspektet ved megling til uttrykk når man ser nærmere på prosessen som førte til gruppens opprettelse. Grunnet intern splid hadde Khazalis enhet begynt å opptre uavhengig fra Jaysh al-Mahdi (JAM), Muqtada al-Sadrs milits, allerede i 2004 (Wyer, 2012). Dette sammenfalt med økt iransk misnøye med Sadr, som i tillegg til å stå bak flere mislykkede opprør hadde inngått en kontroversiell våpenhvile med USA (Knights, 2010; Stanford University, 2017). Som resultat mistet Sadr en viktig kilde til finansiering og annen materiell støtte, til stor bekymring for de mest ytterliggående medlemmene, som var sterkt forpliktet til den væpnede motstanden (Cochrane, 2009, s. 6; Fishman \& Felter, 2008, s. 34). Ifølge Akram al-Kaabi, en sentral skikkelse i AAH, var det på denne tiden gruppen begynte å ta form (Wyer, 2012, s. 12).

I 2004 organiserte Muhandis, som på det tidspunktet var Soleimanis representant i Irak, et møte mellom det iranske lederskapet og flere JAM-medlemmer i Teheran (Wing, 2015). Her skal Iran ha tilbudt Khazali sin fulle støtte, blant annet ved å sette hans enhet i kontakt med Hizbullah (ibid.). I 2005 sendte Teheran en forespørsel til Hizbullah om å bistå med å etablere og trene $\mathrm{AAH}$, noe de gjorde i 2006 etter at IRGC hadde utnevnt Khazali som leder for et nytt nettverk av militser (Cochrane, 2009, s. 6, 18-19; Ostovar, 2016, s. 173; Posch, 2018). Irans rolle i denne prosessen var trolig drevet av et ønske om å forme en milits som var enklere å kontrollere enn JAM, og som i tillegg var uavhengig fra Sadr, som Soleimani betraktet som uforutsigbar (Knights, 2010, s. 13; Wing, 2015). Sadr har selv kritisert Iran for å ha oppfordret sadrister til å forlate JAM og heller samarbeide direkte med Teheran (Wing, 2015). I 2006-2007 ble det også rapportert om flere sammenstøt mellom JAM og Iran-tilknyttede militser som Badr og AAH (Posch, 2018, s. 14; Williams, 2009, s. 83).

I mobiliseringen av $\mathrm{KH}$ ser man lignende tendenser. Iran skal ha støttet Muhandis’ beslutning om å forlate Badr i 2002-2003, for så å opprette en ny milits i 2006 (se Fishman \& Felter, 2008, s. 24; Juneau, 2015, s. 110; Knights, 2010, s. 12). Det ble senere kjent at Badr-medlemmer var involvert i å trene opp både AAH og KH, noe som også indikerer at formasjonen av sistnevnte var en felles beslutning (Posch, 2018, s. 15). I denne sammenheng er det verdt å nevne at Muhandis’ brudd overlappet med SCIRIs og Badrs overgang til politiske aktører, også illustrert ved sistnevntes navnebytte til Badr-organisasjonen for gjenoppbygging og utvikling. I og med at en demokratisk prosess trolig ville la Iraks sjiamajoritet konsolidere makten, var disse aktørenes formelle deltagelse her ansett som ønskelig av Iran (Takeyh, 2008, s. 14). Imidlertid var det fortsatt like viktig å bekjempe USAs militære tilstedeværelse i Irans nabolag (se også Barzegar, 2008, s. 53). I både AAHs og KHs mobiliseringsprosesser kan det dermed se ut til at Iran har både oppfordret og bistått ytterliggående elementer til å danne nye militser. ix

Videre peker empirien på at dette aspektet ved megling har vært mulig grunnet Irans evne til å knytte nære relasjoner til individer. I alle mobiliseringsprosessene ser man at megling har involvert å styrke eller formalisere forbindelser hvor 
både tillit og felles formål allerede eksisterer, illustrert ved at Hakim, Khazali og Muhandis ble valgt som ledere med omhu av Iran. Irans forhold til Muhandis er et godt eksempel i denne sammenheng. Gjennom sin rolle som kommandør i Badr hadde Muhandis samarbeidet tett med IRGC siden 1980-tallet (Knights, 2010, s. 13; Strouse, 2010, s. 4). Soleimani har blant annet referert til Muhandis som «en levende martyr» og "en mujahid med 40 års motstand» (Toumaj, 2017). Under et bilateralt møte mellom Iran og Irak i 2006, samme år som KH ble dannet, satt Muhandis sammen med iranerne, noe som var svært uvanlig (Dehghanpisheh, 2014). Dette kan innebære at en viktig dimensjon i Irans militsstrategi er å velge ideologisk og religiøst likesinnede individer som militsledere for å sikre gruppens lojalitet. Megling ser dermed ut til å være uløselig sammenknyttet med både indoktrinering og koordinert handling.

Iran har en annen tilnærming til det å knytte politiske forbindelser til andre. De går dypt inn $i$ et parti, og hvis de finner hundre måter å skape et forhold til individene der på, gjør de det [Dette giør de] i alle partier, hele tiden [...] I Irak har de et svært omfattende nettverk av denne typen forhold. Når du snakker om innflytelse, er det derfor ikke bare snakk om innflytelse som utøves gjennom [formelle] kanaler. [Iran] er innad i partiene og har nære forbindelser til alle ledere. Iran forsøker alltid å etablere en forbindelse med «kjente» individer, både nåværende ledere og de som potensielt kan bli det. ${ }^{3}$

Iran jobber stort sett ikke gjennom institusjoner i Irak. Iranerne jobber med partier, og innad i partiene bygger de nære relasjoner til utvalgte, mektige individer. Når de støtter disse, får de noe tilbake, som for eksempel lojaliteten til en milits. ${ }^{4}$

Iran forholder seg bare til [militsenes] ledere og kommandører, ikke til soldater. Det eneste unntaket er de dyktigste, som for eksempel skarpskyttere, som trenes opp i Iran. ${ }^{5}$

I tråd med de teoretiske forventningene har imidlertid meglervirksomhet også bestått av nettverksbygging. Det iranske lederskapet bidro vesentlig til å samle de mange irakiske opposisjonsgruppene under SCIRI-paraplyen i tillegg til å støtte og tilrettelegge for det meste av deres aktiviteter (Marinova, 2017, s. 27; Stanford University, 2012; International Crisis Group, 2007, s. 3). Dette fremheves også i SCIRIs egne dokumenter, hvor det står at deres hovedkontor ble etablert i Teheran fordi «Iran hadde tatt imot ayatollah al-Hakim, SCIRIs leder, og tusenvis av irakere som flyktet da Saddam tok over makten i 1979» (Marinova, 2017, s. 29). Selv om de ulike

\footnotetext{
${ }^{3}$ Intervju av Muthana Ameen Nader, leder for Den kurdiske islamske union, Suleimania, Irak, mars 2018.

${ }^{4}$ Intervju av Dlawer Ala'Aldeen, direktør ved Middle East Research Institute, Erbil, Irak, mars 2018.

${ }^{5}$ Intervju av Shakhawan A. Ahmed, visepresident for den irakiske nasjonalforsamlingens sikkerhets- og forsvarskomité, Erbil, Irak, mars 2018.
} 


\title{
Henriette U. Erstad
}

fraksjonene stammet fra den samme sjiaislamistiske bevegelsen i Irak, var det kun Hakim-familien og Dawa-partiet som hadde en formell tilknytning før dette (se også Cole, 2003, s. 547). Megling bestod dermed både av å skape en forbindelse mellom seg selv og opposisjonen, men også av å skape en forbindelse mellom de ulike gruppene. Iran skal også ha lagt til rette for at SCIRI skulle kunne bygge relasjoner til andre irakere som oppholdt seg i Iran, inkludert flyktninger og irakiske krigsfanger (International Crisis Group, 2007; Nakash, 2003; Posch, 2018, s. 12). I AAHs og KHs tilfeller har en viktig del av nettverksbygging vært å koble gruppene med andre i Irans transnasjonale sjianettverk, særlig Hizbullah.

I tillegg til tilbudet om materiell støtte var Irans ikke-materielle ressurser åpenbart avgjørende for Irans bruk av denne mekanismen. Etter 1979 var den såkalte sjiaoppvåkningen i Iran en betydelig inspirasjonskilde for den irakiske opposisjonen så vel som for andre muslimer i regionen som kjempet for politisk endring. Khomeinis panislamske retorikk samt den islamske republikkens selverklærte rolle som talerør for alle undertrykte muslimer bidro derfor utvilsomt til Irans evne til å mobilisere grupper. Selv om det iranske lederskapet trolig også følte en moral forpliktelse til å hjelpe brødre i nød, må dette også ses i forbindelse med Khomeinis uttalte mål om å eksportere revolusjonen. Som argumentert av Ches Thurber (2014, s. 906) var Irans mobilisering av SCIRI også en måte å få «et fotfeste i det irakiske sjiasamfunnet»og «overbevise den religiøse eliten om å omfavne Khomeini som sin spirituelle leder» på.

Lederne i Irak har historisk sett vært sunnier som har undertrykt sjiaer [...] Iran utnyttet den historiske opposisjonen mot Saddam Hussein, som har ført til at irakiske sjiaer har oppfattet Iran som en frigjørende styrke. ${ }^{6}$

\begin{abstract}
Alle sjiagruppene [med tilknytning til Iran] har blitt undertrykt av sunniledere, som har ført til at de har et sekterisk og ideologisk syn på dem som sitter med makten. Iran har utnyttet dette ved å fremstille seg selv som en "frelser» for alle undertrykte sjiaer. ${ }^{7}$
\end{abstract}

Khomeini og den iranske revolusjonen endret mye i Irak og regionen. For første gang ble [en sterk statsleder] som sjahen veltet av demonstranter og ayatollaher, til tross for landets mektige militære. Dette forandret selvtilliten til folket og var en god lærepenge for kurdere og andre etniske grupper i Irak. Det viste nemlig at makt ikke er alt, massene kan også bestemme. ${ }^{8}$

\section{Indoktrinering}

I tråd med diskusjonen over ser indoktrinering ut til å ha vært en mekanisme som Iran har benyttet både før og samtidig med megling. I alle de tre mobiliseringsprosessene

\footnotetext{
${ }^{6}$ Intervju av Arif Qurbani, redaktør i avisen Xendan, Chamchamal, Irak, 5. mars 2018.

${ }^{7}$ Intervju av Kardo Mohammed, seniormedlem i Gorran-bevegelsen, Erbil, Irak, 7. mars 2018.

${ }^{8}$ Intervju av Sadi Ahmed Pire, talsperson for Kurdistans patriotiske union, Erbil, Irak, 7. mars 2018. Pire var selv i opposisjon og mottok støtte fra Iran på denne tiden.
} 
peker empirien på at Iran ikke har vært villig til å skape en nœr forbindelse med ikke-likesinnede grupper og/eller individer. Dette innebærer at ideologisk og religiøs overbevisning kan være en forutsetning for at Iran skal styrke eller formalisere nettopp en slik forbindelse. Et illustrerende eksempel på dette er at selv om Iran forsynte JAM med materiell støtte, ser samarbeidet mellom de to ut til å ha vært et såkalt «bekvemmelighetsekteskap» snarere enn et nært, tillitsbasert forhold. Selv om sadristene i likhet med Iran var dedikerte motstandere av USA, markerte de avstand fra Khomeinis sjiadoktrine (Cochrane, 2009, s. 9-10; International Crisis Group, 2006, s. 4; Smyth, 2015). I og med at forholdet mellom Iran og JAM dermed var basert på et felles mål om å angripe koalisjonsstyrker, opphørte dette som nevnt tidligere i 2004.

Når det gjelder SCIRI, er den mest tydelige indikatoren på indoktrinering lederskapets adopsjon av Irans sjiadoktrine, som representerte et religiøst identitetsskifte fra den sjiaislamistiske bevegelsen i Najaf som de hadde sitt opphav i. Hakim var nemlig den første sjiaislamistiske lederen fra Irak som fremmet Khomeinis sjiadoktrine, og som ønsket å erstatte Baath-regimet med en islamsk republikk tuftet på Velayat-e faqih (Visser, 2007, s. 27; 2011, s. 145-147). Han hadde blant annet en visjon om et "forent sjiarike", hvor Iran og Irak eksplisitt ble nevnt, som skulle styres av en rettslærd (faqih) (ibid.). Det at Khomeini til slutt valgte å anerkjenne Hakim som lederen for den irakiske sjiaopposisjonen, var nok derfor ingen tilfeldighet, selv om det skal ha vært en prosess med ubesluttsomhet - eller til og med forhandlinger mellom de to før Hakim til slutt ble utnevnt (Wiley, 1992, s. 60). Hakim ble deretter referert til som "lederen av Iraks fremtidige islamske stat» av iranske tjenestemenn (Bakhash, 1984, s. 233).

Det jeg har observert, er at Iran tilbyr grupper ideologisk støtte og hjelper dem å utvikle seg til politiske partier før landet forsyner dem med våpen og utstyr. På denne måten «oppfostrer» landet dem og sikrer seg at de har samme mål som Iran, før de transformeres til mektige, politiske aktører [...] Invasjonen i 2003 banet vei for to aktører som videreførte [Irans eksport av revolusjonen]. Gjennom [SCIRI og Badr] plantet Iran et frø som skulle hjelpe dem å praktisere sin ideologi og strategi i Irak. ${ }^{9}$

Jeg er sjia og besøker derfor de hellige mausoleene [i sør-Irak]. Iranerne er overalt - til og med sikkerhetsvaktene er iranske [...] Irakiske sjiaer praktiserer til og med noen av de samme ritualene som iranske sjiaer giør, som skiller seg fra våre. Et eksempel er å slå seg selv til blods med et sverd for å symbolisere at du sympatiserer med drapet på Imam Hussein. Et annet eksempel er at noen sjiaer synger tekstene om Imam Husseins og Imam Abbas' dødsfall med en iransk aksent. Men det mest åpenbare eksempelet er kanskje at irakiske kvinner og jenter bruker en iransk chador. Dette er ikke irakisk - irakere har sine egne unike klesdrakter, men de bruker den likevel. Dette er iranske praksiser som er veldig nye i Irak, og som ble

\footnotetext{
${ }^{9}$ Intervju av Kardo Mohammed, seniormedlem i Gorran-bevegelsen, Erbil, Irak, mars 2018.
} 
introdusert etter 2003. Hvem har introdusert dem i Irak? Det er de som kom fra Iran [SCIRI og Badr]. ${ }^{10}$

Videre ser det ut til at et lignende identitetsskifte har skjedd blant Khazali og hans tilhengere etter deres splittelse med sadristene. Mens Sadrist-bevegelsen som nevnt var uenig i Khomeinis sjiadoktrine, har AAH fremmet Velayat-e faqih siden gruppen ble opprettet (Al-Tamimi, 2014). Dette er bemerkelsesverdig av flere årsaker. For det første var Khazali student av og assistent for storayatollah Mohammad Sadeq al-Sadr, Sadrist-bevegelsens grunnlegger, på 1990-tallet (Wyer, 2012, s. 13). Sistnevnte var en uttalt utfordrer av Khameneis autoritet blant sjiaene i Irak, og han fremmet i tillegg en form for nasjonalisme preget av skepsis til iransk innflytelse (Alaaldin, 2017). Distansen til Iran skal delvis ha vært grunnen til at Saddam Hussein lot bevegelsen utvikle seg som den gjorde på den tiden (International Crisis Group, 2006, s. 4; Krohley, 2014). For det andre ble sadristene igjen i Irak mens de fleste sjiaislamister dro til Iran etter 1979 (Cochrane, 2009, s. 10). Etter Mohammad Sadeq al-Sadr død i 1999 var også Khazali en av de viktigste aktørene med tanke på å holde bevegelsen samlet (Alaaldin, 2017). Det at AAH plutselig forfektet Irans sjiadoktrine, representerte dermed et klart identitetsskifte hos Khazali og hans tilhengere.

I KHs tilfelle kan ikke indoktrinering sies å ha skjedd under selve mobiliseringsprosessen, men snarere under Muhandis, og medlemmenes tid hos SCIRI og Badr. Det at Iran var i stand til å etablere en milits som allerede var religiøst og ideologisk orientert, og i tillegg fremmet iranske interesser i Irak, underbygger også argumentet om at SCIRI og Badr er «vellykkede» tilfeller av indoktrinering.

Iran trenger ikke å bruke myk makt (soft power) for å vinne hjerter og sinn i Irak, [Iran] har irakiske militser som gjør det på vegne av dem i hele landet. ${ }^{11}$

En annen indikator på indoktrinering er også at gruppen, sammen med blant annet $\mathrm{AAH}$, har fremmet den såkalte motstandsaksen, som det transnasjonale sjianettverket ofte omtales som (Levitt \& Smyth, 2015; Majidyar, 2017a). Irans bruk av denne mekanismen har derfor ikke vært begrenset til Velayat-e faqih, men har også inkludert revolusjonære idealer, som motstand mot USAs tilstedeværelse i regionen samt Israels eksistens. Denne delen av Irans revolusjonære tankegods har imidlertid ikke vært særlig fremtredende når det gjelder SCIRI, noe som gir mening i og med at den felles fienden i dette tilfellet først og fremst var Saddam Hussein, ikke USA. I tråd med litteraturen om sekterisk entreprenørskap vektlegger dette at religion ikke kan ses isolert fra det politiske.

[Irans antiamerikanske tankegods] har vært viktig, i stor grad fordi det er noe sannhet i det. USA utnevnte Iran som del av ondskapens akse etter 9/11, selv om

\footnotetext{
${ }^{10}$ Intervju av Yasir Kuoti, forsker ved Middle East Research Institute, Erbil, Irak, mars 2018.

${ }^{11}$ Intervju av Dlawer Ala'Aldeen, Direktør ved Middle East Research Institute, Erbil, Irak, mars 2018.
} 
det ikke fantes iranere blant flykaprerne. Noen sjiaer tolker dette som at Iran blir angrepet fordi de er sjia. I tillegg tror noen irakiske og iranske sjiaer at Saddam ikke kunne holdt på makten uten støtte fra Vesten. Konspirasjon eller ikke, det er veldokumentert at Vesten støttet Saddam under Iran-Irak-krigen, som kostet millioner av sivile livet. Iran skapte dermed ikke den antiamerikanske retorikken av tynn luft - det har noe sannhet i seg - noe som gjør det til et fantastisk språk for å mobilisere mennesker. De som tror på Irans antiamerikanske uttalelser, vil finne bevis for å underbygge dem. For å mobilisere mennesker i Irak og regionen sier de derfor at de går i korstog mot dem som invaderer oss. Dette er en [svært beleilig] måte for dem å dekke over aktivitetene sine på. ${ }^{12}$

For å oppsummere er det indikasjoner på at det har vært en viss variasjon når det kommer til hvordan indoktrinering har funnet sted, selv om mekanismen utvilsomt har blitt brukt i alle de tre mobiliseringsprosessene. I denne sammenhengen er det viktig å understreke at indoktrinering ikke nødvendigvis har vært et mål i seg selv. Det at SCIRI hadde et langsiktig mål om å erstatte Baath-regimet med en islamsk republikk à la den iranske modellen, var nok for eksempel ansett som en måte å sikre iransk innflytelse i Irak over tid på. Det må også ses som en del av Khomeinis uttalte mål om å eksportere revolusjonen. Dette gjelder også AAH og KH, som neste seksjon også vil illustrere.

Forholdet mellom [Iran og sjiamilitsene] er rent pragmatisk. Militslederne tror ikke på iranske verdier, trosretninger, ideologier eller utenrikspolitikk - de bare vet at de er avhengig av Iran for å øke sin makt. Det samme gjelder Iran - de når ikke ut til disse gruppene fordi de er sjia. Sjiareligionen er ikke et mål i seg selv, men et middel for å oppnå et mål. ${ }^{13}$

Dette [indoktrinering] er hvordan de rekrutterer, utøver innflytelse og driver med utpressing. Men hjernene bak det tenker ikke lenger ideologisk - de er imperiebyggere. Hvis du drar til Iran og snakker med dem og forstår dem, innser $\mathrm{du}$ at ideologi ikke betyr noe lenger. ${ }^{14}$

\section{Koordinert handling}

Tilstedeværelsen av delte mål og en felles fiende - og dermed koordinert handling har vært avgjørende for Irans evne til å mobilisere grupper i hele tidsperioden.

Når det gjelder SCIRI, var det ønsket om politisk endring i Irak som gjorde det mulig for Iran å mobilisere de forskjellige opposisjonsgruppene. Den irakiske sjiaopposisjonen var nok fullt klar over at Irans støtte ville øke deres mulighet til å lykkes, og at dette særlig gjaldt dem som ville oppnå det ved bruk av vold. Opprettelsen av

\footnotetext{
${ }^{12}$ Intervju av Yasir Kuoti, forsker ved Middle East Research Institute, Erbil, Irak, mars 2018.

${ }^{13}$ Intervju av Shakhawan A. Ahmed, visepresident for den irakiske nasjonalforsamlingens sikkerhets- og forsvarskomité, Erbil, Irak, mars 2018.

${ }^{14}$ Intervju av Dlawer Ala'Aldeen, direktør ved Middle East Research Institute, Erbil, Irak, mars 2018.
} 


\section{Henriette U. Erstad}

Badr i 1983 var SCIRIs viktigste verktøy i denne sammenheng. På den tiden var Badr en enhet i IRGC, en beslutning iranerne tok for at SCIRI ikke skulle kunne utøve full kontroll over dem (Posch, 2018). Badr kjempet også sammen med den iranske hæren under Iran-Irak-krigen (Jabar, 2003, s. 253). Det at Iran hadde betydelig innflytelse over SCIRI og Badr, underbygges ytterligere ved at de utførte angrep mot Mujahideen-e-Khalq, en militant iransk opposisjonsgruppe som på den tiden oppholdt seg i Irak (International Crisis Group, 2007, s. 3). SCIRI opptrådte i tillegg ofte som et talerør på vegne av iranerne, eksempelvis ved å innta Irans politiske posisjon i møter med andre opposisjonsgrupper, både i Damaskus og andre steder (Wiley, 1992, s. 78). Ulike typer koordinert handling mellom Iran og SCIRI er dermed veldokumentert og var åpenbart en sentral mekanisme i sistnevntes mobiliseringsprosess.

Som nevnt tidligere var Khazalis og Muhandis' sterke forpliktelse til å fortsette den væpnede motstanden dominerende for Irans evne til å mobilisere AAH og KH. Mellom 2006 og 2011 tok AAH på seg ansvaret for mer enn 6000 angrep mot koalisjonsstyrker, noe som ikke hadde vært mulig uten iransk støtte (se Counter Extremism Project, 2018). Grunnet den betydelige militære og finansielle støtten de fikk fra både Iran og Hizbullah, var flere av angrepene svært avanserte operasjoner (ibid.). Det nære samarbeidet mellom dem kom for eksempel tydelig til uttrykk i hendelsesforløpet etter koalisjonsstyrkenes arrestasjon av Khazali, hans bror Laith al-Khazali og Hizbullah-medlem Ali Mussa Daqduq i 2007 (se Knights, 2010, s. 13). To måneder senere var nærmere $100 \mathrm{AAH}-$ medlemmer involvert i kidnappingen av en britisk IT-konsulent og fire sikkerhetsvakter i Bagdad, som ble fraktet til et fengsel i Iran (Mahmood, O'Kane \& Grandjean, 2009; Meikle \& Sturcke, 2010). Operasjonen skal ha vært nøye planlagt av IRGC med det formål å forhandle om løslatelsen av Khazali-brødrene og Daqduq (ibid.).

Koordinert handling var også sentralt i mobilisering av KH. Faktumet at gruppen ble opprettet som en slags «eliteenhet» som skulle fortsette å angripe koalisjonsstyrker, mens moderorganisasjonen utviklet seg til å bli en legitim, politisk aktør, illustrerer dette. I likhet med KH har gruppens militante aktiviteter ofte vært svært avanserte operasjoner som ikke hadde vært mulig uten Iran. KH har blant annet blitt anklaget for å stå bak «noen av de dødeligste angrepene mot amerikanske koalisjonsstyrker» i løpet av deres tilstedeværelse i Irak (Stanford University, 2016). KHs første angrep skal ha vært i 2008 da gruppen avfyrte et improvisert missil (IRAM) mot en amerikansk base i sørøstlige Bagdad (ibid.). KH er kjent for å ha filmet angrepene og publisert dem på nett som del av sin rekrutteringsstrategi (U.S. Department of the Treasury, 2009). Muhandis skal også ha ledet et smuglernettverk som forflyttet militært utstyr fra Iran til Irak, som var avgiørende for både AAH og KHs forsyninger (se Levitt \& Smyth, 2015). Det er dermed velkjent at gruppen har samarbeidet nært med både IRGC og andre Iran-tilknyttede sjiamilitser, inkludert AAH og Hizbullah, om koordinerte handlinger i Irak. Muhandis har uttalt at han er stolt av å være en soldat som ledes av Soleimani, som han også skal ha vært rådgiver for (Knights, 2011, s. 12). 
Iran får [sjiamilitsene] til å gjøre jobben under banneret av irakisk nasjonalisme og at Irak er ett folk. De vet at det ikke ser bra ut å bli sett ved frontlinjen. Så krigerne er irakere, men iranerne er hjernene bak. ${ }^{15}$

Selv om dette har skjedd i senere tid, er det viktig å påpeke at koordinert handling også har utviklet seg til å gjelde utenlandsoperasjoner, som understreker det nære forholdet mellom dem. AAH og KH har blant annet kjempet på vegne av Bashar al-Assad i Syria samt beskyttet landets sjiahelligdommer i tett samarbeid med IRGC, Hizbullah og andre irakiske sjiamilitser med tilknytning til Iran. Ifølge Reuters skal IRGC ha utnevnt en sentral skikkelse i Badr-organisasjonen til å koordinere syriske myndigheter og de Iran-tilknyttede militsene i Syria, inkludert AAH og KH (Al-Salhy, 2013). Flere militsmedlemmer skal ha blitt trent ved en base nær Teheran før avreise til Syria, og AAH og KH skal også ha bistått IRGC med å danne en rekke nye grupper som skulle ta del i Irans militære innsats i borgerkrigen (Clarke \& Smyth, 2017; Dury-Agri, Kassim \& Martin, 2017; Fassihi, Solomon \& Dagher, 2013; Levitt \& Smyth, 2015).

For Qassem Soleimani er de irakiske sjiamilitsene Allah. Syriske enheter, afghanske jihadister, somaliske bevegelser - de har alle likhetstrekk med IRGC. Sjia er ikke lenger en religion, det er en nasjon, en identitet. [Det transnasjonale sjianettverket] er veldig sterkt nå. ${ }^{16}$

De [AAH og andre Iran-tilknyttede sjiamilitser] har alle den samme militære doktrinen [...] De er alle utdannet ved den samme iranske skolen. Det er utvilsomt et høyt nivå av koordinasjon mellom dem, i Syria, Irak og Libanon [...] De er i ferd med å bli én styrke som går under forskjellige navn. ${ }^{17}$

Gruppene har også deltatt i strategisk bruk av språklige virkemidler innenfor den såkalte motstandsaksens repertoar. Når aktører som USA eller Israel kommer med trusler rettet mot Iran, gjengjeldes disse truslene ofte av grupper som AAH og KH (se f.eks. Majidyar, 2018b). I tillegg til motstand mot USAs tilstedeværelse i regionen har de nemlig vært uttalte motstandere av Israels eksistens. Ord har også blitt til handlinger - AAH deltok militært i krigen mellom Israel og Libanon i 2006 (Stanford University, 2018). I desember 2017 var Khazali på omvisning i sørlige Libanon i regi av Hizbullah, noe som ble sterkt kritisert av både israelske og libanesiske politikere (Majidyar, 2018a). AAH har også blitt anklaget for angrepet mot en saudisk grensevakt i 2013 i protest mot Saudi-Arabia innblanding i Irak (Cigar, 2015). Faktumet at koordinert handling har utvidet seg til å involvere flere aspekter ved Irans regionale konfliktlinjer, indikerer at Teheran på pragmatisk vis tilpasser sin

\footnotetext{
${ }^{15}$ Intervju av Dlawer Ala'Aldeen, direktør ved Middle East Research Institute, Erbil, Irak, mars 2018.

${ }^{16}$ Intervju av Sadi Ahmed Pire, talsperson for Kurdistans patriotiske union, Erbil, Irak, 7. mars 2018.

${ }^{17}$ Intervju av Arif Qurbani, redaktør i avisen Xendan, Chamchamal, Irak, 5. mars 2018.
} 


\section{Henriette U. Erstad}

religiøse og ideologiske innflytelse etter egne geopolitiske omgivelser. Det vitner også om en dyp overbevisning blant militsene om at både israelsk tilstedeværelse og vestlig innblanding i regionen må bekjempes, noe som kan være en indikasjon på at indoktrinering er en viktig tilrettelegger for koordinert handling.

Iran fremmer i større grad Israel og Saudi-Arabia som fiender. Iranerne vet at det å være imot USA ikke har like stor påvirkningskraft i Irak som det å være imot Saudi-Arabia og Israel. ${ }^{18}$

Kort oppsummert har Irans kombinasjon av materielle og ikke-materielle ressurser dermed vært avgjørende for koordinert handling i alle tre mobiliseringsprosesser. Mens Iran dro stor nytte av sin ideologiske og religiøse appell for å nå ut til gruppene, var militære og økonomiske midler nødvendig for å sikre at de ville være effektive i kamp. Koordinert handling har også vært en form for skjult og/eller indirekte intervensjon, siden Iran ønsket å forme militser som kunne angripe koalisjonsstyrker uten å svekke både sin og SCIRIs legitimitet i formelle prosesser. Selv om samarbeidet mellom Iran og analyseenhetene har vært fordelaktig for begge parter, har det vært preget av et asymmetrisk maktforhold der gruppene i stor grad har vært avhengig av iranske ressurser for å oppnå sine mål. På et overordnet nivå gir det dermed ikke nødvendigvis mening å skille det ideologiske og religiøse fra det politiske, i tråd med den instrumentelle tilnærmingen til mobilisering.

\section{Sosial tilegnelse}

Selv om sosial tilegnelse har blitt benyttet av en rekke irakiske sjiamilitser i senere tid, peker de empiriske funnene på at denne mekanismen kun har vært fremtredende i mobiliseringen av SCIRI. Den viktigste indikatoren på dette er at Iran finansierte og tilrettela for SCIRIs omfattende sosiale tjenester allerede fra gruppens opprettelse i 1982, noe som blant annet inkluderte driften av 18 barne- og ungdomsskoler i Iran, regelmessige besøk til flyktningleirer, medisinsk hjelp, kontantstøtte og andre velferdstiltak til irakere samt finansiering av kulturelle arrangementer for den irakiske diasporaen i land som Iran, Syria og Storbritannia (se Corboz, 2015; Marinova, 2017). Mekanismen ble dermed aktivt brukt for å øke SCIRIs populære legitimitet blant det store antallet irakiske sjiaer som oppholdt seg utenfor Irak, og særlig i Iran, på denne tiden. Dette kan ha vært av særlig betydning for SCIRI med tanke på at det religiøse etablissementet i Najaf, som er en viktig kilde til legitimitet blant irakiske sjiaer, tok sterk avstand fra organisasjonens militante aktiviteter.

I AAHs tilfelle har mekanismen dukket opp senere fremfor i selve mobiliseringsprosessen. Gruppen begynte nemlig å utvikle seg fra en væpnet motstandsgruppe til en politisk organisasjon etter Khazalis løslatelse i 2010 (se Sly, 2013). Dette ble

\footnotetext{
${ }^{18}$ Intervju av Dlawer Ala'Aldeen, direktør ved Middle East Research Institute, Erbil, Irak, mars 2018.
} 
kunngjort på en pressekonferanse i Najaf den 26. desember 2011, da Khazali meddelte at AAH ønsket å delta i den formelle politiske prosessen i Irak (Wyer, 2012, s. 11). Dette var kort tid etter at president Obama hadde besluttet å trekke amerikanske styrker ut av landet, noe som peker på at dette kan ha vært en måte for AAH å sikre sitt raison d'être i skiftende omgivelser. Det at Iran kan ha hatt en rolle i dette, illustreres blant annet av at det henger portretter av Khomeini og Khamenei i AAHs kontorer i Bagdad, til tross for at gruppen har forsøkt å fremme seg selv som et nasjonalistisk parti (Sly, 2013; Wyer, 2012, s. 15). I og med at dette skjedde flere år etter mobiliseringen av gruppen, ville det derfor ha vært mer meningsfylt å se nærmere på denne mekanismen i en studie av AAHs langsiktige utvikling.

Hos $\mathrm{KH}$ har denne mekanismen imidlertid vært helt fraværende, indikert ved at gruppen verken har lansert en politisk kampanje eller utviklet en velferdsarm. Et nevneverdig unntak er at Muhandis har hatt en rekke offentlige stillinger og blant annet var parlamentsmedlem fra 2005 til 2011 (selv om han stort sett oppholdt seg i Iran) (Knights, 2010). Likevel har KH drevet utelukkende med militante aktiviteter, noe de fortsatt giør den dag i dag. Mens Badr-organisasjonen og AAH var del av den Iran-vennlige valgalliansen al-Fatah under det irakiske parlamentsvalget i 2018, kunngjorde $\mathrm{KH}$ på sin nettside at de ikke kom til å være del av denne alliansen (Nada \& Rowan, 2018).

Selv om Irans rolle i dette har vært vanskelig å kartlegge empirisk, bør det ikke utelukkes at de har vært involvert i beslutningene som har blitt tatt omkring gruppenes utvikling. Med tanke på variasjonen mellom gruppene kan dette være fordi Iran har forskjellige mål for militsene. Mens noen gradvis tar del i politiske prosesser og sikrer iransk innflytelse i formelle kanaler, blir andre brukt taktisk for skjult og/eller indirekte intervensjon. Dette har også blitt påpekt i forbindelse med megling. Variasjonen kan også indikere at Iran anser sosial tilegnelse som noe som må skje over tid. I mobiliseringen av SCIRI kan for eksempel sosial tilegnelse ha vært et langsiktig strategisk grep av Iran for å øke oppslutningen rundt både SCIRI og Iran selv, i og med at det iranske lederskapet ønsket at det sjiairakiske eksilmiljøet skulle konsolidere makten i Irak på sikt. Dette underbygges også av at AAHs transformasjon skjedde i skiftende omgivelser.

\section{Konklusjon}

Denne artikkelen har sett nærmere på hvordan Iran har mobilisert irakiske sjiamilitser siden 1979 ved å ta utgangspunkt i mobiliseringsprosessene til Det øverste råd for islamsk revolusjon i Irak, Asa'ib Ahl al-Haq og Kata'ib Hizbullah. Mens de empiriske funnene har pekt på en viss variasjon i bruk av mobiliseringsmekanismer, antyder prosessporingen en potensiell årsakskjede for hvilken rekkefølge de har blitt brukt i. Samtidig må det understrekes at mekanismene er så uløselig sammenknyttet at det ikke nødvendigvis gir mening å stykke opp mobiliseringsprosessene på en systematisk måte. Som et analytisk grep har denne fremgangsmåten likevel vært illuminerende for å forstå hvordan Iran har gått frem. 


\section{Henriette U. Erstad}

I samtlige mobiliseringsprosesser er det indikasjoner på at indoktrinering har kommet først, mens megling og koordinert handling har fulgt tett etter. Den mest fremtredende indikatoren på indoktrinering er at analyseenhetene har forfektet Khomeinis sjiadoktrine Velayat-e faqih, som representerte et religiøst identitetsskifte fra den sjiaislamistiske bevegelsen i Najaf, som de hadde sitt opphav i. I tillegg har revolusjonære idealer, som motstand mot utenlandsk innblanding og særlig USAs tilstedeværelse i regionen, styrket Irans evne til å mobilisere etter 2003. Tilstedeværelsen av felles mål og fiender - og dermed et grunnlag for koordinert handling - har imidlertid lagt til rette for dette. Som sådan er det viktig å påpeke at det ikke nødvendigvis gir mening å skille det ideologiske og religiøse fra det politiske, i tråd med sekterisk entreprenørskaps instrumentelle tilnærming til mobilisering.

Videre er et teoretisk uventet funn at megling i stor grad også har bestått av å frakoble tidligere tilkoblede enheter. Dette ser ut til å ha vært en slags splitt-og-herskteknikk for i større grad å kunne utøve kontroll over militser. Under okkupasjonstiden ser det dessuten ut til å ha vært et strategisk grep for å påvirke utviklingen i Irak både nedenfra og opp via væpnet motstand og ovenfra og ned via Iran-tilknyttede aktørers deltagelse i formelle prosesser. Irans evne til å knytte nære relasjoner til likesinnede enkeltindivider har i stor grad gjort dette mulig, noe som igjen har bidratt til $\mathrm{i}$ å sikre gruppenes lojalitet. Iran har dermed bidratt til en økning av antall militser i Irak ved å oppfordre mer ytterliggående elementer til å danne nye grupper. Et annet uventet funn er at sosial tilegnelse kun har blitt brukt i mobiliseringen av SCIRI. Denne mekanismen kan derfor være mer interessant for en studie som ser nærmere på den langsiktige utviklingen av denne typen grupper, samt på hvordan de tilpasser seg skiftende omgivelser.

Kort oppsummert antyder de empiriske funnene at Iran har opptrådt som en sekterisk entreprenør som har brukt både materielle og ikke-materielle ressurser til å mobilisere likesinnede militser til å delta i kollektiv vold og fremme felles krav. Iran har dermed på pragmatisk vis kombinert økonomiske og militære maktmidler med sin ideologiske og religiøse appell for å delta i skjult og/eller indirekte konfliktintervensjon i regionen. Selv om dette ikke betyr at Iran har aktivert sekteriske spenninger og vold i Irak, har det utvilsomt utnyttet eksisterende skillelinjer i det irakiske samfunn for å fremme egne interesser.

\section{Om forfatteren}

Henriette Ullavik Erstad er forskningsassistent i forskningsgruppen Fred, konflikt og utvikling ved Norsk Utenrikspolitisk Institutt (NUPI). Hun har en mastergrad i statsvitenskap fra Universitetet i Oslo.

\section{Om artikkelen}

En stor takk til IPs redaktører og til komiteen som tildelte denne artikkelen Ordingprisen 2018. Takk rettes også til Kjetil Selvik og Målfrid Braut-Hegghammer for 
uvurderlig veiledning, samt til Tine Gade for innsiktsfulle kommentarer underveis i prosessen. Feltarbeidet i Irak hadde ikke vært mulig Khogir Wirya Mohammed og Dlawer Ala'Aldeen. En ekstra takk til Øyvind Svendsen som sørget for at artikkelen ble til.

\section{Litteraturliste}

Adamson, F. B. (2013). Mechanisms of diaspora mobilization and the transnationalization of civil war. I J. T. Checkel (Red.), Transnational dynamics of civil war. UK: Cambridge University Press.

Al-Rasheed, M. (2017). Sectarianism as counter-revolution: Saudi responses to the Arab Spring. I N. Hashemi \& D. Postel (Red.), Sectarianization: Mapping the new politics of the Middle East. London, UK: C. Hurst \& Co.

Al-Salhy, S. (2013, 10. april). Iraqi Shi'ite militants start to acknowledge role in Syria. Reuters. Hentet fra https://www.reuters.com/article/us-syria-crisis-iraq-idUSBRE9390OB20130410

Al-Tamimi, A. J. (2014, august 31). Saraya al-Khorasani 31 August statement: Translation and nnalysis. Hentet 24. januar 2018, fra Aymenn Jawad Al-Tamimu website: http://www.aymennjawad.org/2014/08/saraya-alkhorasani-31-august-statement

Al-Tamimi, A. J. (2017, 31. oktober). Hashd Brigade Numbers Index. Aymenn fawad Al-Tamimi. Hentet fra http://www.aymennjawad.org/2017/10/hashd-brigade-numbers-index

Alaaldin, R. (2017). The origins and ascendancy of Iraq's Shiite militias. Current Trends in Islamist Ideology, 22, 143-160.

Alaaldin, R. (2018, 30. mars). How Iran used the Hezbollah model to dominate Iraq and Syria. The New York Times. Hentet fra https:/www.nytimes.com/2018/03/30/opinion/iran-hezbollah-iraq-syria.html

Arango, T. (2017, 15. juli). Iran dominates in Iraq after U.S. 'handed the country over'. The New York Times. Hentet fra https://www.nytimes.com/2017/07/15/world/middleeast/iran-iraq-iranian-power.html

Bakhash, S. (1984). The reign of the Ayatollahs: Iran and the Islamic revolution. Basic Books.

Bakke, K. M. (2013). Copying and learning from outsiders? Assessing diffusion from transnational insurgents in the Chechen wars. I J. T. Checkel (Red.), Transnational dynamics of civil war. UK: Cambridge University Press.

Bapat, N. A. (2012). Understanding state sponsorship of militant groups. British fournal of Political Science, $42(1), 1-29$.

Barzegar, K. (2008). Iran's foreign policy in post-invasion Iraq. Middle East Policy, 15(4), 47-58.

Cigar, N. (2015). Iraq's Shi'a warlords and their militias: Political and security challenges and options. Hentet fra https://ssi.armywarcollege.edu/pdffiles/PUB1272.pdf

Clarke, C., \& Smyth, P. (2017). Implications of Iran's expanding Shi'a foreign fighter network. CTC Sentinel, $10(10), 14-18$.

Cochrane, M. (2009). The fragmentation of the Sadrist movement (Nr. 12). Institute for the Study of War.

Cole, J. (2003). The United States and Shi'ite religious factions in post-Ba'thist Iraq. The Middle East Fournal, $57(4), 543-566$.

Corboz, E. (2015). Guardians of Shi'ism: Sacred authority and transnational family networks. Edinburgh: Edinburgh University Press.

Counter Extremism Project. (2018). Asaib Ahl al-Haq | Counter Extremism Project. Hentet 2. september 2019, fra Counter Extremism Project website: https://www.counterextremism.com/threat/asaib-ahl-al-haq

David, C. (1998). Writing security: United States foreign policy and the politics of identity. Minneapolis: University of Minnesota Press.

Dehghanpisheh, B. (2014, 12. november). Special report: The fighters of Iraq who answer to Iran. Reuters. Hentet fra https://www.reuters.com/article/us-mideast-crisis-militias-specialreport/special-report-thefighters-of-iraq-who-answer-to-iran-idUSKCNOIW0ZA20141112

Della Porta, D., \& Diani, M. (2006). Social movements: An introduction (2. utg.). Blackwell Publishing.

Dury-Agri, J. R., Kassim, O., \& Martin, P. (2017, desember). Iraqi security forces and popular mobilization forces: Orders of battle. Hentet 4. januar 2018, fra Institute for the Study of War website: http://www. understandingwar.org/report/iraqi-security-forces-and-popular-mobilization-forces-orders-battle-0

Eisenstadt, M., \& Knights, M. (2017, 9. mai). Mini-Hizballahs, revolutionary guard knock-offs, and the future of Iran's militant proxies in Iraq. Hentet 2. september 2019, fra War on the Rocks website: https:// warontherocks.com/2017/05/mini-hizballahs-revolutionary-guard-knock-offs-and-the-future-of-iransmilitant-proxies-in-iraq/ 


\section{Henriette U. Erstad}

Fassihi, F., Solomon, J., \& Dagher, S. (2013, 16. september). Iranians dial up presence in Syria. Wall Street fournal. Hentet fra https:/www.wsj.com/articles/iranians-dial-up-presence-in-syria-1379298675

Fishman, B., \& Felter, J. (2008, 13. oktober). Iranian strategy in Iraq. Hentet 23. november 2017, fra Combating Terrorism Center at West Point website: https://ctc.usma.edu/iranian-strategy-in-iraq-politics-and-othermeans/

Grynkewich, A. G. (2008). Welfare as warfare: How violent non-state groups use social services to attack the state. Studies in Conflict E Terrorism, 31(4), 350-370.

Haddad, F. (2018, 5. mars). Understanding Iraq's Hashd al-Sha'bi. Hentet 2. april 2018, fra The Century Foundation website: https://tcf.org/content/report/understanding-iraqs-hashd-al-shabi/

Hashemi, N., \& Postel, D. (2017). Sectarianization: Mapping the new politics of the Middle East. London: C. Hurst \& Co.

Hashim, A. (2005). Insurgency and counter-insurgency in Iraq. Ithaca, NY: Cornell University Press.

International Crisis Group. (2006). Iraq's Muqtada Al-Sadr: Spoiler or stabiliser? (Nr. 55). Hentet fra International Crisis Group website: https://d2071andvip0wj.cloudfront.net/55-iraq-s-muqtada-al-sadrspoiler-or-stabiliser.pdf

International Crisis Group. (2007). Shïte politics in Iraq: The role of the Supreme Council | Crisis Group (Nr. 70). Hentet fra International Crisis Group website: https://www.crisisgroup.org/middle-east-north-africa/gulfand-arabian-peninsula/iraq/shiite-politics-iraq-role-supreme-council

Jabar, F. A. (2003). The Shī ite movement in Iraq. Saqi.

Juneau, T. (2015). Squandered opportunity: Neoclassical realism and Iranian foreign policy. Stanford: Stanford University Press.

Knights, M. (2010). The evolution of Iran's special groups in Iraq. CTC Sentinel, 3(11-12), 12-16.

Knights, M. (2011). Shia strength - Iraqi militants adapt to the US drawdown. Fane's Intelligence Review. Hentet fra https:/www.washingtoninstitute.org/uploads/Documents/opeds/4e8b0eba7c0a2.pdf

Knights, M. (2019). Iran's expanding militia army in Iraq: The new special groups. CTC Sentinel, 12(7). Hentet fra https://ctc.usma.edu/irans-expanding-militia-army-iraq-new-special-groups/

Krohley, N. (2014, 7. august). Moqtada al-Sadr's difficult relationship with Iran. Hentet 12. februar 2014, fra HURST website: https://www.hurstpublishers.com/moqtada-al-sadrs-difficult-relationship-with-iran/

Levitt, M., \& Smyth, P. (2015). Kataib al-Imam Ali: Portrait of an Iraqi Shïte militant group fighting ISIS (policy analysis nr. 2352). Hentet 3. mars 2018 fra The Washington Institute for Near East Policy website: https:// www.washingtoninstitute.org/policy-analysis/view/kataib-al-imam-ali-portrait-of-an-iraqi-shiite-militantgroup-fighting-isis

Lynch, M. (2013, 13. november). The entrepreneurs of cynical sectarianism. Foreign Policy. Hentet 26. februar 2018 fra https://foreignpolicy.com/2013/11/13/the-entrepreneurs-of-cynical-sectarianism/

Mahmood, M., O'Kane, M., \& Grandjean, G. (2009, 31. desember). Revealed: Iran's involvement in Britons' Baghdad kidnapping. The Guardian. Hentet fra https:/www.theguardian.com/world/2009/dec/31/petermoore-kidnapping-iran-militia

Majidyar, A. (2017a, 11. mai). Iran-controlled militant group says regional alliance will create "Shiite full moon". Hentet 2. september 2017, fra Middle East Institute website: https://www.mei.edu/publications/ iran-controlled-militant-group-says-regional-alliance-will-create-shiite-full-moon

Majidyar, A. (2017b, 25. september). Iran has emerged as the main victor in Iraq. Hentet 12. oktober 2017, fra Middle East Institute website: https://www.mei.edu/publications/iran-has-emerged-main-victor-iraq

Majidyar, A. (2018a, 14. februar). Another Iran-backed Iraqi militia leader visits Lebanon, threatens Israel. Hentet 15. februar 2018, fra Middle East Institute website: https:/www.mei.edu/publications/anotheriran-backed-iraqi-militia-leader-visits-lebanon-threatens-israel

Majidyar, A. (2018b, 23. juli). Iraqi Hezbollah threatens retaliation against U.S. if Israel attacks Iranian assets in Iraq. Hentet 12. september 2019, fra Middle East Institute website: https://www.mei.edu/publications/ iraqi-hezbollah-threatens-retaliation-against-us-if-israel-attacks-iranian-assets-iraq

Marinova, N. K. (2017). Ask what you can do for your (new) country: How host states use diasporas. Oxford, UK: Oxford University Press.

Matthiesen, T. (2014, 12. desember). Beware of entrepreneurs in sectarian identity [Mondiaal Nieuws]. Hentet fra https://www.mo.be/en/interview/beware-entrepreneurs-ins-sectarian-identity

McAdam, D., McCarthy, J. D., Zald, M. N., \& Mayer, N. Z. (1996). Comparative perspectives on social movements: Political opportunities, mobilizing structures, and cultural framings. Cambridge: Cambridge University Press.

Meikle, J., \& Sturcke, J. (2010, 12. mars). Torture and table tennis: Iraq hostage Peter Moore recounts life in captivity. The Guardian. Hentet fra https:/www.theguardian.com/world/2010/mar/12/peter-moorerecounts-iraq-captivity 


\section{Stater og transnasjonale motstandsnettverk}

Nada, G., \& Rowan, M. (2018, 27. april). Part 2: Pro-Iran militias in Iraq. Hentet 3. mars 2019, fra Wilson Center website: https://www.wilsoncenter.org/article/part-2-pro-iran-militias-iraq

Nakash, Y. (2003). The Shi'is of Iraq. Princeton University Press.

Nasr, V. (2017). International politics, domestic imperatives, and identity mobilization: Sectarianism in Pakistan, 1979-1998. I N. Hashemi \& D. Postel (Red.), Sectarianization: Mapping the new politics of the Middle East. Oxford, UK: C. Hurst \& Co.

Ostovar, A. (2016). Vanguards of the Imam: Religion, politics, and Iran's revolutionary guards. Oxford: Oxford University Press.

Pierpaoli Jr., P. G. (2013). Supreme Iraqi Islamic Council. I R. R. Mockaitis (Red.), The Iraq war encyclopedia. ABC-CLIO.

Posch, W. (2018). Schiitische Milizen im Irak und in Syrien. Hentet 2. april 2018 fra https://www.academia. edu/34182023/Schiitische_Milizen_im_Irak_und_in_Syrien

Roggio, B. (2007, 20. august). Mahdi army trains with Hezbollah. Hentet 2. februar 2018, fra FDD's Long War Journal website: //www.longwarjournal.org/archives/2007/08/mahdi_army_trains_wi.php

Roggio, B. (2008, 23. februar). Mugniyah behind establishment of Mahdi army. Hentet 14. januar 2018, fra FDD's Long War Journal website: //www.longwarjournal.org/archives/2008/02/mugniyah_behind_esta. php

Romano, D. (2017). Social movement theory and political mobilization in Kurdistan. I G. Stansfield \& M. Shareef (Red.), The Kurdish question revisited. Oxford, UK: Oxford University Press.

Rousseau, J.-J. (1968). The social contract. Baltimore: Penguin Books.

Sadeghi-Boroujerdi, E. (2017). Strategic depth, counterinsurgency, and the logic of sectarianization: The Islamic of Iran's security doctrine and its regional implications. I N. Hashemi \& D. Postel (Red.), Sectarianization: Mapping the new politics of the Middle East. London, UK: C. Hurst \& Co.

Selvik, K. (2018). Religiøs autoritet og tynnslitt stat. Valgkamp i sjia-Irak. Babylon Nordisk tidsskrift for Midtøstenstudier, (2), 56-67. https://doi.org/10.5617/ba.6726

Shanahan, R. (2004). Shi'a political development in Iraq: The case of the Islamic Dawa Party. Third World Quarterly, 25(5), 943-954.

Sly, L. (2013, 18. februar). Iranian-backed militant group in Iraq is recasting itself as a political player. Washington Post.

Smyth, P. (2015, februar). The Shiite jihad in Syria and its regional effects - The Washington Institute for Near East Policy. Hentet 2. september 2019, fra The Washington Institute website: https://www. washingtoninstitute.org/policy-analysis/view/the-shiite-jihad-in-syria-and-its-regional-effects

South, T. (2019, 4. februar). Army's long-awaited Iraq war study finds Iran was the only winner in a conflict that holds many lessons for future wars. Hentet 8. mars 2019, fra Army Times website: https://www. armytimes.com/news/your-army/2019/01/18/armys-long-awaited-iraq-war-study-finds-iran-was-theonly-winner-in-a-conflict-that-holds-many-lessons-for-future-wars/

Sowell, K. H. (2015, 23. april). The rise of Iraq's militia state. Hentet 2. februar 2018, fra Carnegie Endowment for International Peace website: https://carnegieendowment.org/sada/59888

Stanford University. (2012, 5. august). Mapping militant organizations | Supreme Council for Islamic Revolution in Iraq. Hentet 2. september 2019, fra Stanford University website: http://web.stanford.edu/ group/mappingmilitants/cgi-bin/groups/view/405?highlight=Mahdi+Army

Stanford University. (2016, 25. august). Mapping militant organizations | Kata'ib Hezbollah. Hentet 2. september 2019, fra http:/web.stanford.edu/group/mappingmilitants/cgi-bin/groups/view/361?highlight= kataib+hezbollah

Stanford University. (2017, 26. november). Mapping militant organizations | Mahdi Army. Hentet 2. september 2019, fra Stanford University website: http://web.stanford.edu/group/mappingmilitants/cgibin/groups/view/57

Stanford University. (2018, juli). Mapping militant organizations | Asa'ib Ahl al-Haq. Hentet 2. september 2019, fra Stanford University website: https://cisac.fsi.stanford.edu/mappingmilitants/profiles/asaib-ahl-al-haq

Staniland, P. (2015). Militias, ideology, and the state. Fournal of Conflict Resolution, 59(5), 770-793.

Strouse, T. (2010, 4. mars). Kata'ib Hezbollah and the intricate web of Iranian military involvement in Iraq. Hentet 24. mars 2018, fra Jamestown Terrorism Monitor website: https://jamestown.org/program/kataibhezbollah-and-the-intricate-web-of-iranian-military-involvement-in-iraq/

Takeyh, R. (2008). Iran's new Iraq. The Middle East fournal, 62(1), 13-30.

Thurber, C. (2014). Militias as sociopolitical movements: Lessons from Iraq's armed Shia groups. Small Wars E Insurgencies, 25(5-6), 900-923.

Tilly, C., \& Tarrow, S. (2015). Contentious politics (2. utg.). Oxford, UK: Oxford University Press. 


\section{Henriette U. Erstad}

Toumaj, A. (2017, 13. juli). Iran's Qods force chief calls Iraqi militia commander a «living martyr». Hentet 11. februar 2018, fra FDD's Long War Journal website: //www.longwarjournal.org/archives/2017/07/iransqods-force-chief-calls-iraqi-militia-commander-living-martyr.php

Toumaj, A. (2018, 23. mars). Death of a general: What Shaban Nasiri reveals about Iran's secretive Qods force. Hentet 28. mars 2018, fra War on the Rocks website: https://warontherocks.com/2018/03/death-ofa-general-what-shaban-nasiri-reveals-about-irans-secretive-qods-force/

Varshney, A. (2007). Ethnicity and ethnic conflict. I C. Boix \& S. C. Stokes (Red.), The Oxford handbook of comparative politics (Bd. 4). Oxford, UK: Oxford University Press.

Visser, R. (2007). Basra, the reluctant seat of «Shiastan» (Nr. 242; s. 23-28). Hentet fra MERIP website: https:// merip.org/2007/03/basra-the-reluctant-seat-of-shiastan/

Visser, R. (2011). Religious allegiances among pro-Iranian special groups in Iraq. CTC Sentinel, 4(9). Hentet 22. november 2017 fra https://ctc.usma.edu/religious-allegiances-among-pro-iranian-special-groupsin-iraq/

Vogt, K. (2012). Husets folk: shia-Islam $i$ det 21. århundre. Oslo: Cappelen Damm.

Wehrey, F. M. (2014). Sectarian politics in the Gulf: From the Iraq war to the Arab uprisings. Columbia University Press.

Wiley, J. N. (1992). The Islamic movement of Iraqi Shi'as. Boulder, CO: Lynne Rienner Publishers.

Williams, P. (2009). Criminals, militias, and insurgents: Organized crime in Iraq. Carlisle Barracks, PA: Strategic Studies Institute.

Wing, J. (2015). Inside the Moqtada Al-Sadr - Qais Khazali split within Iraq's Sadr. Hentet 2. oktober 2018 fra https://www.academia.edu/13951754/Inside_The_Moqtada_Al-Sadr_Qais_Khazali_Split_Within_ Iraq_s_Sadr_Trend_Interview_With_Al_Rais_Elijah_Magnier

Wood, E. J. (2013). Transnational dynamics of civil war: Where do we go from here? I J. T. Checkel (Red.), Transnational dynamics of civil war. UK: Cambridge University Press.

Wyer, S. (2012). The resurgence of Asa'ib Ahl Al-Haq (nr. 7). Hentet 17. oktober 2018 fra Institute for the Study of War website: http://www.understandingwar.org/sites/default/files/ResurgenceofAAH.pdf

Yamao, D. (2008). Transformation of the Islamic Da'wa Party in Iraq: From the revolutionary period to the diaspora era. Asian and African Area Studies, 7(2), 238-267.

\section{Vedlegg I.}

\begin{tabular}{|c|c|c|}
\hline \multicolumn{3}{|r|}{$\begin{array}{c}\text { Intervjuobjekter } \\
\text { (alle intervjuer gjenomført i Irak 1.-15. mars 2018) }\end{array}$} \\
\hline & Navn & Tilhørighet \\
\hline 1 & Shakhawan A. Ahmed & $\begin{array}{l}\text { Medlem, Kurdistans demokratiske parti (KDP) } \\
\text { Representant, Iraks nasjonalforsamling } \\
\text { Visepresident, Den irakiske nasjonalforsamlingens sikkerhets- og } \\
\text { forsvarskomité }\end{array}$ \\
\hline 2 & Dlawer Ala'Aldeen & $\begin{array}{l}\text { President, Middle East Research Institute } \\
\text { Tidligere kunnskapsminister, Kurdistans regionale myndighet, Irak }\end{array}$ \\
\hline 3 & Sadi Ahmed Pire & $\begin{array}{l}\text { Talsperson, Kurdistans patriotiske union (PUK) } \\
\text { Medlem, PUKs utenrikskomité } \\
\text { Tidligere karrierediplomat, Iraks utenriksdepartement }\end{array}$ \\
\hline 4 & Arif Qurbani & Redaktør, Xendan \\
\hline 5 & Muthana Ameen Nader & $\begin{array}{l}\text { Leder, Kurdistans islamske union } \\
\text { Representant, Iraks nasjonalforsamling } \\
\text { Medlem, Den irakiske nasjonalforsamlingens utenrikskomité }\end{array}$ \\
\hline 6 & Kardo Mohammed & $\begin{array}{l}\text { Seniormedlem, Gorran-bevegelsen } \\
\text { Representant, Gorran-bevegelsens nasjonale råd }\end{array}$ \\
\hline 7 & Hassan Barram & $\begin{array}{l}\text { Seniormedlem, Koalisjon for demokrati og rettferdighet i Kurdistan } \\
\text { Tidligere seniormedlem, Kurdistans patriotiske union (PUK) }\end{array}$ \\
\hline 8 & Yasir Kuoti & Forsker, Middle East Research Institute \\
\hline
\end{tabular}




\section{Sluttnoter}

i. For enkelhetens skyld vil det refereres til Iran som en helhetlig aktør i denne artikkelen, til tross for at det ville vært mer meningsfylt å skille mellom de mange, ofte konkurrerende institusjonene i Den islamske republikkens politiske system og (u)formelle maktstrukturer. Det er veldokumentert at denne dimensjonen av Irans regionale politikk utformes av øverste leder og hans maktapparat, for så å implementeres av Den iranske revolusjonsgarden (IRGC). Regjeringen og parlamentet har derfor begrenset innflytelse over Irans mobilisering av væpnede grupper. Å referere til Iran som en enhetlig aktør er derfor en forenkling av virkeligheten, men forsvares ved det faktum at øverste leder til syvende og sist er både Den islamske republikkens og IRGCs høyeste autoritet.

ii. Se f.eks. Gotts, I. (2018). Alternative Governance - Non-state armed groups and the Iraqi reconstruction process (Research Paper Nr. 3). Hentet fra Konrad-Adenauer-Stiftungs nettside https:/www.kas.de/c/ document_library/get_file?uuid=7b8a214e-2f46-0b48-c9c5-d24918834da6\&groupId=252038; Gotts, I. (2019, 27. mai). PMU economic offices undermine fragile stability in Mosul. Hentet 5. september 2019 fra Al-Monitors nettside: https:/www.al-monitor.com/pulse/originals/2019/05/iraq-economymosul-pmu.html; Haddad, F. (2018, 5. mars). Understanding Iraq's Hashd al-Sha'bi. Hentet 2. april 2018 fra The Century Foundations nettside: https://tcf.org/content/report/understanding-iraqs-hashdal-shabi/; Knights, M. (2019). Iran's Expanding Militia Army in Iraq: The New Special Groups. CTC Sentinel, 12(7). Hentet fra https://ctc.usma.edu/irans-expanding-militia-army-iraq-new-special-groups/; O'Driscoll, D. \& Van Zoonen, D. (2017). The Hashd al-Shaabi and Iraq: Subnationalism and the state. Middle East Research Institute. Hentet fra http:/www.meri-k.org/wp-content/uploads/2017/03/PMFReport-0.2.pdf

iii. Den islamske republikken har også jobbet via andre kanaler for å styrke sin posisjon i Irak. se f.eks. Selvik, K. (2019). Religiøs autoritet og tynnslitt stat. Valgkamp i sjia-Irak. Babylon, 2(2018). DOI: http://dx.doi. org $/ 10.5617 / \mathrm{ba} .6726$

iv. Forfatteren er ikke kjent med andre tilfeller der en stat har hatt en lignende strategi for mobilisering av væpnede opprørere utenfor egne landegrenser.

v. Se f.eks. Bapat, N. A. (2012). Understanding state sponsorship of militant groups. British fournal of Political Science, 42(1), 1-29; Salehyan, I., Gleditsch, K. S. \& Cunningham, D. E. (2011). Explaining external support for insurgent groups, International Organiation, 65(4), 709-744.

vi. Se f.eks. Byman, D., Chalk, P., Hoffman, B., Rosenau, W. \& Brannan, D. (2001). Trends in outside support for insurgent movements. Santa Monica, CA: Rand Corporation.

vii. Se f.eks. Khatib, L., Matar, D. \& Alshaer, A. (2014). The Hizbullah Phenomenon: Politics and Communication. London, UK: C. Hurst \& Co.; Koya, A. R. K. (2006). Hizbullah, Party of God: An Islamic Movement Perspective. New York: The Other Press.

viii. For en utfyllende gjennomgang, se Erstad, H. U. (2018). Transnational Networks of Armed Resistance: How Iran has mobilised Iraqi Shi'a militias since 1979. Masteroppgave, Institutt for statsvitenskap. Oslo: Universitetet i Oslo. Tilgjengelig fra: https:/www.duo.uio.no/bitstream/handle/10852/63955/Grafiske. pdf?sequence $=1$ \&isAllowed=y

ix. Dette skal Iran også ha gjort med medlemmer i Libanons Amal-parti i opprettelsen av Hizbullah på 1980-tallet. Se Levitt, M. \& Smyth, P. (2015). Kataib al-Imam Ali: Portrait of an Iraqi Shiite Militant Group Fighting ISIS (Policy Analysis Nr. 2352). Hentet 4. oktober 2018 fra The Washington Institute for Near East Policys nettside: https://www.washingtoninstitute.org/policy-analysis/view/kataib-al-imam-aliportrait-of-an-iraqi-shiite-militant-group-fighting-isis

\footnotetext{
Abstract in English

The Islamic Republic of Iran has been building a transnational network of Shi'a militias since 1979, commonly referred to as its asymmetric warfare capability and 'strategic depth'. While it is a known fact that Iran has mobilised Shi'a militias in other countries to strengthen its regional position, how they have done it has not received much scholarly attention. The objective of this paper is to explain this phenomenon by examining how Iran has mobilised Iraqi Shi'a militias since 1979. The selected cases are the mobilisation
} 
processes of three most prominent Shi'a militias in Iraq today: Badr Organisation, Asa'ib Ahl al-Haq, and Kata'ib Hizbullah. Although variation exists between them, they are all cases of Iran's network of armed resistance groups, which have allowed it to engage in covert or indirect conflict intervention in the Middle East. To logically connect the empirical data with the study's research question, I have used a case study research design, with process tracing and the semi-structured interview as methods for data collection. Furthermore, the empirical analysis has been guided by a theoretical framework that has attempted to build a bridge between the existing literatures on state-militia dynamics and contentious politics.

Keywords: mobilisation • sectarian entrepreneurship · Iran · Iraq • Middle East 